International Journal of English Literature and Social Sciences
Vol-6, Issue-5; Sep-Oct, 2021

Peer-Reviewed Journal

\title{
Factors affecting the quality of financial statements on investment decision making
}

\author{
Bayar Gardi ${ }^{1}$, Pshdar Abdalla Hamza ${ }^{2}$, Khowanas Saeed Qader ${ }^{3}$, Hawkar Anwar \\ Hamad $^{4}$, Dr. Govand Anwar ${ }^{5}$
}

\begin{abstract}
${ }^{1}$ Department of Accounting, College of Administration and Financial Sciences, Knowledge University, Kirkuk Road, 44001 Erbil, Kurdistan Region, Iraq.

${ }^{2}$ Department of Business Administration, Kurdistan Technical Institute, Sulaymaniyah, Iraq.

${ }^{3}$ Department of Accounting and Finance, College of Administrations and Economics, Lebanese French university, Kurdistan region, Iraq. ${ }^{4}$ Department of Accounting and Finance, College of Administrations and Economics, Lebanese French university, Kurdistan region, Iraq. ${ }^{5}$ Business Administration, Global University of Erbil, Kurdistan region, Iraq.
\end{abstract}

Received: 20 Sep 2021; Received in revised form: 14 Oct 2021; Accepted: 20 Oct 2021; Available online: 28 Oct 2021 (C2021 The Author(s). Published by Infogain Publication. This is an open access article under the CC BY license (https://creativecommons.org/licenses/by/4.0/).

\begin{abstract}
Since Kurdistan is expanding, it is getting more economically strong, and it thus requires a large amount of cash to carry out various developmental tasks. Individual investors' investment behavior must be studied in order to find the reasons that encourage people to invest. This will allow idle savings to be channeled into investment, which will help to increase the amount of money available for investment among individuals. There are several factors that impact investment decisions. The fact that financiers hold a dominant position in the financial market is an unavoidable truth. The behavior of investors is not predictable. It varies from one job to another, as well as from one level of protection to another. The identification of the elements that impact investment decisions is therefore important. It is important to understand how individuals invest in the securities and other financial alternatives that are accessible in order to boost investment and create suitable theories and regulations.
\end{abstract}

Keywords_Financial Statement, Investment, Accounting, Finance, Decision Making.

\section{INTRODUCTION}

Due to deregulation of the Kurdistan financial industry, the country has experienced unexpected development in the investment sector, both in terms of volume and in terms of the number of investors during the last several decades. This growth has been attributed to deregulation of the Kurdistan financial sector. The number of regional stock exchanges in Kurdistan has increased dramatically in recent years. Equity shares are the alternative that has come a long way merely to provide investors with greater dividend expectations in addition to the best level of capital appreciation (Hamza et al. 2021). Due to the fact that investors are more worried about the amount of money they must spend when making investments, the new idea of book building has been introduced to help improve price discovery for initial public offerings and future public offerings (Sabir et al. 2021).
Retail participation in the stock market has increased dramatically in recent years, as evidenced by data provided by the National Stock Exchange and the Bombay Stock Exchange. The National Stock Exchange has attracted approximately 6,50,000 new participants on its stand during the first six months of the financial year 2012. In a similar vein, the Bombay Stock Exchange (BSE) has seen an increase of 1.3 million participants (Aziz et al. 2021). It has been observed that retail investors account for a relatively small share of the Kurdistan equities market. In Kurdistan, just about 1.5 percent of the population invests in securities, compared to almost 10 percent in China and 18 percent in the United States, respectively (Ahmed et al. 2021). Only $7 \%$ of Kurdistan's family savings are invested in the equity sector of the market, whereas the long-term average in the United States is $33 \%$ of total savings. According to the 
changes in the Kurdistan culture, individuals are required to manage their money in order to fulfill their financial objectives, which may develop during the various phases of life (Ismael et al. 2021). These goals may include retirement, children's education, and health care (Sahi, 2009). With the development of new financial markets and the proliferation of investment goods, it is becoming increasingly important to better understand Kurdistan investors in order to target the appropriate financial product and their purchasing behavior (Ali et al. 2021). There are a variety of elements that impact the investment decisionmaking of retail investors. Because retail investors do not make huge investments, they are more concerned with the security of their funds and make extremely intelligent choices (Gardi, 2021). Different investors have different factors on which they base their investment decisions. Behavioural finance has been shown to have a significant influence in the decision-making process in the investing industry (Qader et al. 2021). According to Hamad et al. (2021), the term "behavioural finance" refers to a facet of finance that is explored in their paper. Specifically, it investigates and discusses aspects of human psychology as well as their implications for making investing decisions in the financial markets (Fatah et al. 2021). Some unexpected information from psychology, sociology, and finance is also being used to provide light on the odd behavior of financiers that has been lacking from standard financial models (Ali \& Hamad, 2021). As a result of individual investors' status as regulation natives, behavioral finance is able to assess the population in the real world. This is because individual investors are regulation natives who are exaggerated by a variety of factors, including factors of demography, psychology, economy, society, and organization (Hamad, 2018). It may be argued that bankers make prudent judgments, but that their decisions are also influenced by a variety of factors. They become too optimistic while they are experiencing pleasant emotions, yet when they are experiencing negative emotions, they tend to condemn, accuse, or become highly suspicious (Ali \& Anwar, 2021). Furthermore, given the rapid increase in the amount of money that investors are putting into their investments, it is necessary to investigate the many types of behavior that investors exhibit. This research comprises the investigation of the determinants of investment choice (Anwar \& Shukur,2015), which will be followed by a survey performed among the respondents using factor analysis and descriptive statistics in order to determine the most important element influencing their investment decision (Anwar \& Abdullah, 2021).

\section{LITERATURE REVIEW}

It is becoming increasingly important to make investment decisions since there is a general increase in job possibilities and the economic development of a country. Working people's capacity and readiness to save and utilise their resources for returns has increased as a result of their increased awareness of investment opportunities (Abdullah \& Anwar, 2021). It was in this context that this study was carried out. Anwar \& Shukur, (2015) performed a study to explore the relationship between investment preferences and demographic factors, as well as to identify and analyze the key differences between investment preferences and risk level among a sample of 120 personalities (Anwar \& Abd Zebari, 2015). They came to the conclusion that women are more intimidation resistant than men, whereas undeveloped and sophisticated persons are intrigued further on the way to fresh precarious investment opportunities and the need to spend their money, but they are hesitant due to a lack of resources, a lack of investment opportunities, and a lack of investment trends, respectively (Anwar \& Surarchith, 2015). When it comes to accumulation, the prevalence of repeated concerns such as religious issues, non-conducive monetary environments, and ethos are proven to be the most important variables to consider when making investment selections. Anwar, (2017) conducted an investigation with the goal of determining the factors that affect investors' decisions to invest in stocks listed on the Nairobi Stock Exchange (Anwar \& Louis, 2017). They investigate or establish that the most important factors that influence the investment decisions of individuals are the reputation of the firm, its status in the industry, the earnings of the corporation that are anticipated, the condition of the profit and loss statement, the stock performance of the firm in the past, the price of a particular share, the sensitivity of the economy, and predictable returns by financiers (Anwar, 2015). Some research also suggest that there is a link between financial knowledge and making an investing decision (Hameed \& Anwar, 2018). This study was performed with 228 questionnaire surveys of investors, and the results were analyzed to determine the level of financial knowledge based on the characteristics that were demographic in nature. It was shown that females have superior financial skills when compared to males, that persons aged 41-50 were more familiar with the skills when compared to individuals in other age groups, and that financial awareness is strongly related with educational attainment (Abdullah et al. 2017). Furthermore, participants in a group with extensive financial knowledge had a higher acceptance level for all financial products, with the exception of certificates of deposit and post office savings, than the rest of the field. Also of note is that participants in a group with less financial understanding tended to favor 
safe and traditional goods of finance and did not engage as much in challenging goods of finance that are relatively tough to get but might yield a high rate of return on investment. The investment choice is also influenced by the relationship that exists between potential private financiers' views about risk taking, personality attributes, and attitudes toward investment decisions (Anwar \& Balcioglu, 2016). The findings revealed that various personality qualities have an impact on an individual's risk-tolerance behaviors, which, in turn, have an impact on investing decisions regarding stocks, bonds, and other types of financial instruments. As a result, while providing investment advice to private clients, financial advisors must take into account a variety of criteria such as individual characteristics and risk tolerance, among others (Anwar, 2016). It was the goal of Islamolu and colleagues (2015) to investigate the factors that influence the behavior of individual investors. Banks provided the statistics used in the investigation, which were obtained using a survey approach (Anwar, 2017). Following the conclusion of the investigation, it was discovered that six factors influenced investor behavior on an individual basis. It was discovered that the link between "aware investor behavior" and "banking and payment behavior" was the most significant of the three (Anwar \& Ghafoor, 2017). We were able to demonstrate that there was a statistically significant relationship between the factors influencing financiers' decision-making for investing on an individual basis (Anwar \& Qadir, 2017). Gender is one of the most significant demographic characteristics to consider when making investing decisions. Anwar \& Climis, (2017) set out to investigate the disparities in the process of making investment decisions between female and male financial professionals. The findings of this study revealed that males have a higher degree of consciousness when it comes to various investment opportunities than women, and that women tend to be less certain about their investment decisions and, as a result, have lower levels of contentment. The internal capital markets play an important role in the devolution of investment decision-making authority (Anwar \& Louis, 2017). In order to do this, it emphasizes the role played by the internal capital market in the distribution of control and decision-making powers as a factor that clarifies the usefulness of investmentmanagement practices. The authors want to apply the idea of organizational architecture to investment decisions in order to better understand the complexity and efficiency of such decisions (Anwar, 2015). However, even though organizational complication has an immediate and negative impact (the polar opposite of what is expected) on the devolution of investment decisions that generate value, it appears that there is a positive relationship between the improbability of the situation and a negative relationship between the shortage and sharing of financial resources between units on the internal capital market, as demonstrated by this research (Hamza et al. 2021). Ali \& Anwar, (2021) investigated the theory of behavioural finance in order to determine the characteristics that influence the investing decisions of individual investors. Following a comprehensive examination of the literature, it was discovered that there is no one element that impacts an individual's investing decisions. Furthermore, the elements that influence an investment choice differ from person to person, from time to time, from security to security, and from location to location. In order to introduce any new investment avenues to the market, it was proposed that policymakers for investment avenues take into account all of the elements and their influence on the investor's investment decisions (Anwar \& Shukur,2015). According to Anwar \& Abdullah, (2021), their research aims to increase knowledge about key influential factors for investment behavior and the ways in which these factors impact speculation risk forbearance and the decisionmaking process between males and females, as well as among different age groups, in order to improve financial literacy. According to their findings, the age of investors and their gender are the most important factors determining their willingness to take risks (Abdullah \& Anwar, 2021). Also in their analysis, Anwar \& Shukur, (2015) go into detail on the relationship between risk level and investor demographic variables. A negative link was discovered between gender, age, nuptial status, educational qualification, and the investor's understanding of the market, it was discovered In addition, there is a positive relationship between cities, income level, and investor expertise. The level of financial literacy of an investor has a major impact on their decision-making. A well-informed investor will be able to make more suitable decisions than a less well-informed investor will be able to make (Anwar \& Abd Zebari, 2015). A research conducted on investors in the United Arab Emirates assessed their level of literacy as well as the most important elements that influence their investing decision-making (Anwar \& Surarchith, 2015). The degree of financial literacy is shown to be exaggerated by the level of money, the amount of time spent at work, and the level of education a person has. The findings demonstrate that there is a significant relationship between investing decisions and financial expertise in general. The religious reason is the most important element influencing investment decisions, while rumor was the factor with the least influence on investment decisions (Anwar, 2017). When it comes to portfolio diversification (Anwar \& Louis, 2017), research was conducted with the goal of quality controling on the lack of financial knowledge as a credible characteristic that might help to alleviate the low levels of 
portfolio diversification that were previously observed (Anwar, 2015). The writers believe in different elements of financial knowledge and manage for differences in socioeconomic and behavioral characteristics among different groups of investors, according to their beliefs (Hameed \& Anwar, 2018). The findings show that investors' experience, financial literacy level, familiarity bias, portfolio size, age, and usage of the availability heuristic all have a substantial influence on the variety of assets included in their portfolios, according to the findings (Abdullah et al. 2017). The researchers' goal in conducting their research was to explore the collision of behavioural elements such as heuristics, fear of risk, the use of financial tools, and corporate governance at the firm's level of decision-making when it came to making investment decisions (Anwar \& Balcioglu, 2016). The findings of the study indicate that heuristics, the use of financial tools, and corporate governance at the firm's level all have an optimistic and significant impact on investment decisions, but risk aversion has a pessimistic and significant impact on investment decisions (Anwar, 2016). Furthermore, all elements that are behavioural, corporate at the firm's level, and investment decision-making of investment decisions have an optimistic and significant relationship with one another. In addition, another study by Anwar, (2017) was carried out in order to analyze the variables that impact investing decisions in the context of individual investors. The research was conducted with 600 individual investors, and the results of the study revealed the most important elements that affect their decisions. According to the findings of the study, there is a significant difference between respondents' investment period, investor type, respondent's age, respondent's marital status, educational skill, profession, annual income, and place of residence, as well as their overall factors that influence investment decisions (Anwar \& Ghafoor, 2017). However, there is no significant difference between male and female respondents when it comes to the overall factors that impact investing decisions. Anwar \& Qadir, (2017) hoped to discover an alternate strategy to fostering financial literacy in order to manage the enormous private money owing burden that this large portion of the population was burdened with over the course of their research. The underlying purpose of the model is to serve as a comprehensive road map to guide universities and other organizations through the process of conceptualizing, setting up, organizing, implementing, and evaluating systems and processes related to financial education that are intended to improve long-term financial decisions and students' financial well-being (Ismael et al. 2021).

\section{METHODOLOGY}

The current research was focused on the city of Erbil, as a consequence of the results, a structured questionnaire was developed and sent to 100 respondents based on the convenience sample methodology. There were around 87 responses received. Individual investors provided the information that was used to compile this report. Only a portion of the questionnaire was approved. For the sake of this example, we are using a range of age groups since we think that a person begins to earn at a certain age. Analysis of the data was carried out in accordance with conventional methods of factor analysis.

\section{Conceptual Framework}

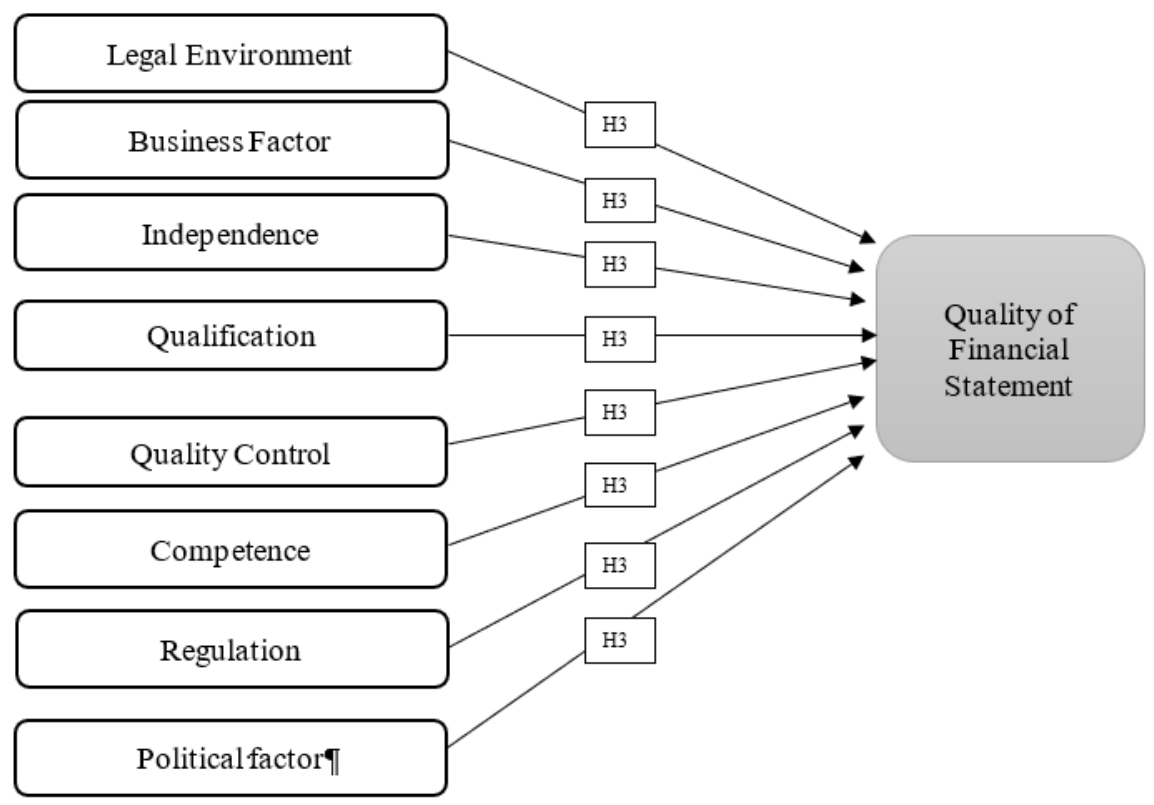




\section{Research Hypotheses:}

H1: Legal environment has a positive influence on the quality of financial statement.

$\mathrm{H} 2$ : Business factor has a positive influence on the quality of financial statement.

H3: Independence has a positive influence on the quality of financial statement.

H4: Qualification has a positive influence on the quality of financial statement.

H5: Quality control has a positive influence on the quality of financial statement.

H6: Competence has a positive influence on the quality of financial statement.

H7: Regulation has a positive influence on the quality of financial statement.

H8: Political factor has a positive influence on the quality of financial statement.

\section{ANALYSIS AND FINDINGS}

Reliability test

Table 1. Reliability Test

\begin{tabular}{|l|c|c|}
\hline \multicolumn{1}{|c|}{ Variable } & $\begin{array}{c}\text { Cronbach's } \\
\text { Alpha }\end{array}$ & No. of Items \\
\hline Legal environment & .815 & 5 \\
\hline Business factor & .770 & 5 \\
\hline Independence & .895 & 7 \\
\hline Qualification & .745 & 5 \\
\hline Quality control & .733 & 5 \\
\hline Competence & .786 & 5 \\
\hline Regulation & .767 & 5 \\
\hline Political factor & .787 & 6 \\
\hline $\begin{array}{l}\text { Quality of financial } \\
\text { statement }\end{array}$ & .734 & 6 \\
\hline
\end{tabular}

As seen in table (1), the reliability tests for the current study, the researchers finds out the Alpha for legal environment $=.815$ for five items since .815 is greater than 6 Correlation analysis
(Kothari,2005), therefore all dimensions utilized for legal environment found to be reliable for this study, the value of Alpha for business factor $=.770$ for five dimensions, it was found that all five dimensions utilized for business factor found to be reliable, the value of Alpha for independence $=.895$ for ten dimensions, it was found that all seven dimensions utilized for independence found to be reliable, the value of Alpha for qualification $=.745$ for six dimensions, it was found that all seven dimensions utilized for qualification found to be reliable, the value of Alpha for quality control $=.733$ for six dimensions, it was found that all five dimensions utilized for quality control found to be reliable, the value of Alpha for competence $=.786$ for five dimensions, it was found that all six dimensions utilized for competence strategy found to be reliable, the value of Alpha for regulation $=.767$ for five dimensions, it was found that all six dimensions utilized for competence strategy found to be reliable, the value of Alpha for political factor $=.787$ for five dimensions, it was found that all six dimensions utilized for competence strategy found to be reliable, and the value of Alpha for quality of financial statement $=.734$ for five dimensions, it was found that all six dimensions utilized for competence strategy found to be reliable.

Table 2. Correlation Analysis

\begin{tabular}{llc}
\hline \multirow{2}{*}{ Variables } & Pearson Correlation & \multicolumn{2}{c}{$\begin{array}{c}\text { Quality of financial } \\
\text { statement }\end{array}$} \\
\hline Legal environment & & $.186^{* *}$ \\
\cline { 2 - 3 } & Sig. (2-tailed) & .000 \\
\cline { 2 - 3 } & $\mathrm{N}$ & 87 \\
\hline Business factor & & $.307^{* *}$ \\
\cline { 2 - 3 } & Sig. (2-tailed) & .000 \\
\cline { 2 - 3 } & $\mathrm{N}$ & 444
\end{tabular}




\begin{tabular}{|c|c|c|}
\hline \multirow[t]{3}{*}{ Independence } & & $.061^{* *}$ \\
\hline & Sig. (2-tailed) & .000 \\
\hline & $\mathrm{N}$ & 87 \\
\hline \multirow[t]{3}{*}{ Qualification } & & $.161^{\text {*** }}$ \\
\hline & Sig. (2-tailed) & .000 \\
\hline & $\mathrm{N}$ & 87 \\
\hline \multirow[t]{3}{*}{ Quality control } & & $.155^{* *}$ \\
\hline & Sig. (2-tailed) & .000 \\
\hline & $\mathrm{N}$ & 87 \\
\hline \multirow[t]{3}{*}{ Competence } & & $.077^{* *}$ \\
\hline & Sig. (2-tailed) & .000 \\
\hline & $\mathrm{N}$ & 87 \\
\hline \multirow[t]{3}{*}{ Regulation } & & $.224^{* *}$ \\
\hline & Sig. (2-tailed) & .000 \\
\hline & $\mathrm{N}$ & 87 \\
\hline \multirow[t]{3}{*}{ Political factor } & & $.132^{* * *}$ \\
\hline & Sig. (2-tailed) & .000 \\
\hline & $\mathrm{N}$ & 87 \\
\hline
\end{tabular}

As seen in table (2), the correlation analysis, it can be seen that the growth as independent variable has significantly correlated, $r=.186^{* *}$ this demonstrates that there is a weak correlation between growth as independent variable and quality of financial statement as dependent variable, concerning business factor as independent variable has significantly correlated, $\mathrm{r}=.307^{* *}$ this demonstrates that there is a weak correlation between business factor as independent variable and quality of financial statement as dependent variable, concerning independence as independent variable has significantly correlated, $r=.061^{* *}$ this demonstrates that there is a weak correlation between independence as independent variable and quality of financial statement as dependent variable, qualification as independent variable has significantly correlated, $r=.161^{* *}$ this demonstrates that there is a weak correlation between qualification as independent variable and quality of financial statement as dependent variable, concerning quality control as independent variable has significantly correlated, $\mathrm{r}=.155^{* *}$ this demonstrates that there is a weak correlation between quality control as independent variable and quality of financial statement as dependent variable, concerning competence as independent variable has significantly correlated, $r=.077^{* *}$ this demonstrates that there is a weak correlation between competence as independent variable and quality of financial statement as dependent variable, concerning regulation as independent variable has significantly correlated, $r=.224^{* *}$ this demonstrates that there is a weak correlation between regulation as independent variable and quality of financial statement as dependent variable, and concerning political factor as independent variable has significantly correlated, $r$ 
$=.132^{* *}$ this demonstrates that there is a weak correlation between political factor as independent variable and quality of financial statement as dependent variable. The findings indicated that the generally the correlation between dependent factor and independent factors are weak.

\section{Multiple Regression Analysis}

Table 3. Multiple Regression Analysis

\begin{tabular}{lccc}
\hline Independent variable & Coefficients & t-value & P-value \\
\hline Growth & .135 & 1.578 & .001 \\
\hline Business factor & .260 & 2.498 & .000 \\
\hline Independence & .129 & 1.376 & .001 \\
\hline Qualification & .131 & .603 & .005 \\
\hline Quality control & .090 & .438 & .005 \\
\hline Competence & .779 & 2.498 & .000 \\
\hline Regulation & .285 & 1.775 & .000 \\
\hline Political factor & .315 & .882 & .000 \\
\hline R $^{2}$ & .076 & & \\
\hline F value & 5.946 & & \\
\hline
\end{tabular}

Dependent Variable: Quality of financial statement

The researchers utilized multiple regression method to examine the relationship between each independent factor and dependent factor. In this section the researchers attempted to find the relationship between eight independent variables and quality of financial statement as dependent variable. As seen in table (3) the result of first hypotheses, legal environment has significantly predicted quality of financial statement (the value Beta $=.135$, $\mathrm{p}<.001$, therefore the researchers came to conclude that growth has significant relationship quality of financial statement accordingly the first research hypothesis supported, the result of first hypotheses, business factor has significantly predicted quality of financial statement (the value Beta $=.260, \mathrm{p}<.001$, therefore the researchers came to conclude that business factor has significant relationship quality of financial statement accordingly the second research hypothesis supported, the result of third hypotheses, independence has significantly predicted quality of financial statement (the value Beta $=.129$, $\mathrm{p}<.001$, therefore the researchers came to conclude that independence has significant relationship quality of financial statement accordingly the third research hypothesis supported, the result of fourth hypotheses, qualification has significantly predicted quality of financial statement (the value Beta $=.131, \mathrm{p}<.001$, therefore the researchers came to conclude that qualification has significant relationship quality of financial statement accordingly the fourth research hypothesis supported, the result of fifth hypotheses, quality control has significantly predicted quality of financial statement (the value Beta $=.090, \mathrm{p}<.001$, therefore the researchers came to conclude that quality control has significant relationship quality of financial statement accordingly the fifth research hypothesis supported, the result of sixth hypotheses, competence strategy has significantly predicted quality of financial statement (the value Beta $=.779, \mathrm{p}<.001$, therefore the researchers came to conclude that competence has significant relationship quality of financial statement accordingly the sixth research hypothesis supported, the result of seventh hypotheses, regulation has significantly predicted quality of financial statement (the value Beta = $.285, \mathrm{p}<.001$, therefore the researchers came to conclude that regulation has significant relationship quality of financial statement accordingly the seventh research hypothesis supported and finally the result of eighth hypotheses, political factor has significantly predicted quality of financial statement (the value Beta $=.315$, $\mathrm{p}<.001$, therefore the researchers came to conclude that political factor has significant relationship quality of financial statement accordingly the eight research hypothesis supported. It was found that the quality of 
financial statement ${ }^{\text {e' }}$ s overall difference could be measured by its variance. The value of $\mathrm{R}$ square $=.275$ this indicates that $28 \%$ of total variation in quality of financial statement has been explained by all independent variables, and the value $\mathrm{F}$ in this analysis for all independent variables = 10.816 , it is greater than 1 as seen in table above, therefore; there is a significant relation between all independent variables and dependent variable.

\section{CONCLUSION}

The researchers' goal in conducting their research was to explore the collision of behavioural elements such as heuristics, fear of risk, the use of financial tools, and corporate governance at the firm's level of decision-making when it came to making investment decisions (Anwar \& Balcioglu, 2016). The findings of the study indicate that heuristics, the use of financial tools, and corporate governance at the firm's level all have an optimistic and significant impact on investment decisions, but risk aversion has a pessimistic and significant impact on investment decisions (Anwar, 2016).

The researchers utilized multiple regression method to examine the relationship between each independent factor and dependent factor. In this section the researchers attempted to find the relationship between eight independent variables and quality of financial statement as dependent variable. As seen in table (3) the result of first hypotheses, legal environment has significantly predicted quality of financial statement (the value Beta $=.135$, $\mathrm{p}<.001$, therefore the researchers came to conclude that growth has significant relationship quality of financial statement accordingly the first research hypothesis supported, the result of first hypotheses, business factor has significantly predicted quality of financial statement (the value Beta $=.260, \mathrm{p}<.001$, therefore the researchers came to conclude that business factor has significant relationship quality of financial statement accordingly the second research hypothesis supported, the result of third hypotheses, independence has significantly predicted quality of financial statement (the value Beta $=.129$, $\mathrm{p}<.001$, therefore the researchers came to conclude that independence has significant relationship quality of financial statement accordingly the third research hypothesis supported, the result of fourth hypotheses, qualification has significantly predicted quality of financial statement (the value Beta $=.131, \mathrm{p}<.001$, therefore the researchers came to conclude that qualification has significant relationship quality of financial statement accordingly the fourth research hypothesis supported, the result of fifth hypotheses, quality control has significantly predicted quality of financial statement (the value Beta $=.090, \mathrm{p}<.001$, therefore the researchers came to conclude that quality control has significant relationship quality of financial statement accordingly the fifth research hypothesis supported, the result of sixth hypotheses, competence strategy has significantly predicted quality of financial statement (the value Beta $=.779, \mathrm{p}<.001$, therefore the researchers came to conclude that competence has significant relationship quality of financial statement accordingly the sixth research hypothesis supported, the result of seventh hypotheses, regulation has significantly predicted quality of financial statement (the value Beta $=$ $.285, \mathrm{p}<.001$, therefore the researchers came to conclude that regulation has significant relationship quality of financial statement accordingly the seventh research hypothesis supported and finally the result of eighth hypotheses, political factor has significantly predicted quality of financial statement (the value Beta $=.315$, $\mathrm{p}<.001$, therefore the researchers came to conclude that political factor has significant relationship quality of financial statement accordingly the eight research hypothesis supported. It was found that the quality of financial statement" s overall difference could be measured by its variance. The value of $\mathrm{R}$ square $=.275$ this indicates that $28 \%$ of total variation in quality of financial statement has been explained by all independent variables, and the value $\mathrm{F}$ in this analysis for all independent variables = 10.816 , it is greater than 1 as seen in table above, therefore; there is a significant relation between all independent variables and dependent variable.

\section{REFERENCES}

[1] Moşteanu, N. R., \& Faccia, A. (2020). Digital Systems and New Challenges of Financial Management-FinTech, XBRL, Blockchain and Cryptocurrencies. Quality-Access to Success Journal, 21(174), 159-166.

[2] Anwar, G., \& Abdullah, N. N. (2021). Inspiring future entrepreneurs: The effect of experiential learning on the entrepreneurial intention at higher education. International Journal of English Literature and Social Sciences, 6.

[3] Ali, B. J., \& Anwar, G. (2021). Business strategy: The influence of Strategic Competitiveness on competitive advantage. International Journal of Electrical, Electronics and Computers, 6(2).

[4] He, P., Niu, H., Sun, Z., \& Li, T. (2020). Accounting index of COVID-19 impact on Chinese industries: A case study using big data portrait analysis. Emerging Markets Finance and Trade, 56(10), 2332-2349.

[5] Ali, B. J., \& Anwar, G. (2021). A study of knowledge management alignment with production management: A study of carpet manufacture in Kurdistan region of Iraq. Ali, BJ, \& Anwar, G.(2021). A Study of Knowledge Management Alignment with Production Management: a Study of Carpet Manufacture in Kurdistan Region of Iraq. International 
Journal of English Literature and Social Sciences, 6(2), 346360.

[6] Putra, Y. M. (2019). Analysis of Factors Affecting the Interests of SMEs Using Accounting Applications. Journal of Economics and Business, 2(3), 818-826.

[7] Ali, B. J., \& Anwar, G. (2021). Strategic leadership effectiveness and its influence on organizational effectiveness. International Journal of Electrical, Electronics and Computers, 6(2).

[8] Coyne, J. G., \& McMickle, P. L. (2017). Can blockchains serve an accounting purpose?. Journal of Emerging Technologies in Accounting, 14(2), 101-111.

[9] Ali, B. J., Saleh, P. F., Akoi, S., Abdulrahman, A. A., Muhamed, A. S., Noori, H. N., \& Anwar, G. (2021, May). Impact of Service Quality on the Customer Satisfaction: Case study at Online Meeting Platforms. In Ali, BJ, Saleh, Akoi, S., Abdulrahman, AA, Muhamed, AS, Noori, HN, Anwar, G.(2021). Impact of Service Quality on the Customer Satisfaction: Case study at Online Meeting Platforms. International journal of Engineering, Business and Management (Vol. 5, No. 2, pp. 65-77).

[10] Bebbington, J., Russell, S., \& Thomson, I. (2017). Accounting and sustainable development: Reflections and propositions. Critical Perspectives on Accounting, 48, 2134.

[11] Ali, B. J., \& Anwar, G. (2021). Organization citizenship behaviour as a determining Factor in Business outcome. Ali, BJ, \& Anwar, G.(2021). Organization citizenship behaviour as a determining Factor in Business outcome. International journal of Rural Development, Environment and Health Research, 5(2), 17-25.

[12] Pratama, F. A., Kaslani, K., Nurdiawan, O., Rahaningsih, N., \& Nurhadiansyah, N. (2020, March). Learning Innovation Using the Zahir Application in Improving Understanding of Accounting Materials. In Journal of Physics: Conference Series (Vol. 1477, No. 3, p. 032018). IOP Publishing.

[13] Ali, BJ, \& Anwar, G.(2021). Marketing Strategy: Pricing strategies and its influence on consumer purchasing decision. International journal of Rural Development, Environment and Health Research, 5(2), 26-39.

[14] Hall, M., \& O'Dwyer, B. (2017). Accounting, nongovernmental organizations and civil society:: The importance of nonprofit organizations to understanding accounting, organizations and society. Accounting, Organizations and Society.

[15] Ali, B. J., \& Anwar, G. (2021). Intellectual capital: A modern model to measure the value creation in a business. Ali, BJ, \& Anwar, G.(2021). Intellectual capital: A modern model to measure the value creation in a business. International journal of Engineering, Business and Management, 5(2), 31-43.

[16] Anwar, G., \& Shukur, I. (2015). the impact of recruitment and selection on job satisfaction: Evidence from private school in Erbil. International Journal of Social Sciences \& Educational Studies, 1(3), 4-13.

[17] Bonsón, E., \& Bednárová, M. (2019). Blockchain and its implications for accounting and auditing. Meditari Accountancy Research.
[18] Anwar, G., \& Abd Zebari, B. (2015). The Relationship between Employee Engagement and Corporate Social Responsibility: A Case Study of Car Dealership in Erbil, Kurdistan. International Journal of Social Sciences \& Educational Studies, 2(2), 45.

[19] Dillard, J., \& Vinnari, E. (2019). Critical dialogical accountability: From accounting-based accountability to accountability-based accounting. Critical Perspectives on Accounting, 62, 16-38.

[20] Fatah, N. A., Hamad, H. A., \& Qader, K. S. (2021). The Role of Internal Audit on Financial Performance Under IIA Standards: A Survey Study of Selected Iraqi Banks. QALAAI ZANIST SCIENTIFIC JOURNAL, 6(2), 1028-1048.

[21] Ali, D. J., \& Hamad, H. A. (2021). The role of the cash flow statement to provide accounting information for the financial decision-making process:(Case study International Islamic Bank of Kurdistan in the year 2018). QALAAI ZANIST SCIENTIFIC JOURNAL, 6(2), 870-887.

[22] HAMAD, H. (2018). Customer Satisfaction In Banking Sector: The Case In North Iraq, City Of Erbil.

[23] Olatunji, O. C., \& Ayodele, K. B. (2017). Impact Of Information Technology On Tax Administration In Southwest Nigeria. Archives of Business Research, 5(9), 139-150.

[24] Ali, B. J., \& Anwar, G. (2021). The Effect of Marketing Culture Aspects of Healthcare Care on Marketing Creativity. Ali, BJ, \& Anwar, G.(2021). The Effect of Marketing Culture Aspects of Healthcare Care on Marketing Creativity. International Journal of English Literature and Social Sciences, 6(2), 171-182.

[25] Khuntia, J., Saldanha, T. J., Mithas, S., \& Sambamurthy, V. (2018). Information technology and sustainability: Evidence from an emerging economy. Production and Operations Management, 27(4), 756-773.

[26] Ali, B. J., \& Anwar, G. (2021). An Empirical Study of Employees' Motivation and its Influence Job Satisfaction. Ali, BJ, \& Anwar, G.(2021). An Empirical Study of Employees' Motivation and its Influence Job Satisfaction. International Journal of Engineering, Business and Management, 5(2), 21-30.

[27] Oláh, J., Karmazin, G., Pető, K., \& Popp, J. (2018). Information technology developments of logistics service providers in Hungary. International Journal of Logistics Research and Applications, 21(3), 332-344.

[28] Anwar, G., \& Shukur, I. (2015). The Impact of Training and Development on Job Satisfaction: A Case Study of Private Banks in Erbil. International Journal of Social Sciences \& Educational Studies, 2(1), 65.

[29] Ali, B. J., \& Anwar, G. (2021). Factors Influencing the Citizens' Acceptance of Electronic Government. International journal of Engineering, Business and Management (IJEBM), 5.

[30] Nayyar, A., \& Singh, I. (2018). A comprehensive analysis of Goods and Services Tax (GST) in India. Indian Journal of Finance, 12(2), 57-71.

[31] Ali, B. J., \& Anwar, G. (2021). The balanced scorecard's evolution as a strategic mechanism at banking sectors. Ali, BJ, \& Anwar, G.(2021). The Balanced Scorecard'S 
Evolution as a Strategic Mechanism at Banking Sectors. International Journal of English Literature and Social Sciences, 6(1), 471-478.

[32] Anwar, G., \& Abdullah, N. N. (2021). The impact of Human resource management practice on Organizational performance. International journal of Engineering, Business and Management (IJEBM), 5.

[33] Abdullah, N. N., \& Anwar, G. (2021). An Empirical Analysis of Natural Gas as an Alternative Fuel for Internal Transportation. International Journal of English Literature and Social Sciences, 6(1).

[34] Tronchin, L., Manfren, M., \& Nastasi, B. (2018). Energy efficiency, demand side management and energy storage technologies-A critical analysis of possible paths of integration in the built environment. Renewable and Sustainable Energy Reviews, 95, 341-353.

[35] Anwar, G., \& Shukur, I. (2015). Job satisfaction and employee turnover intention: A case study of private hospital in Erbil. International Journal of Social Sciences \& Educational Studies, 2(1), 73.

[36] Anwar, G., \& Shukur, I. (2015). The Impact of Service Quality Dimensions on Students' Satisfaction. International Journal of Social Sciences \& Educational Studies, 76.

[37] Bebbington, J., \& Unerman, J. (2020). Advancing research into accounting and the UN sustainable development goals. Accounting, Auditing \& Accountability Journal.

[38] Lev, B. (2019). Ending the accounting-for-intangibles status quo. European Accounting Review, 28(4), 713-736.

[39] Anwar, G., \& Surarchith, N. K. (2015). Factors Affecting Shoppers' Behavior in Erbil, Kurdistan-Iraq. International Journal of Social Sciences \& Educational Studies, 1(4), 10.

[40] Pincus, K. V., Stout, D. E., Sorensen, J. E., Stocks, K. D., \& Lawson, R. A. (2017). Forces for change in higher education and implications for the accounting academy. Journal of Accounting Education, 40, 1-18.

[41] Ali, B. J., \& Anwar, G. (2021). Measuring competitive intelligence Network and its role on Business Performance. International Journal of English Literature and Social Sciences, 6(2).

[42] Bebbington, J., \& Unerman, J. (2018). Achieving the United Nations Sustainable Development Goals: an enabling role for accounting research. Accounting, Auditing \& Accountability Journal.

[43] Ostaev, G. Y., Khosiev, B. N., Nekrasova, E. V., Frantsisko, O. Y., Markovina, E. V., \& Kubatieva, L. M. (2019). Improving the methodology for assessing the efficiency of labor in organizations of the agroindustrial complex: strategic accounting and analysis. Indo American Journal of Pharmaceutical Sciences, 6(5), 9114-9120.

[44] Ali, B. J., \& Anwar, G. (2021). Self-Leadership Skills as Intangible Resources for Sustainable Competitive Advantage. Advanced Engineering Science, 46(1).

[45] Bebbington, J., Österblom, H., Crona, B., Jouffray, J. B., Larrinaga, C., Russell, S., \& Scholtens, B. (2019). Accounting and accountability in the Anthropocene. Accounting, Auditing \& Accountability Journal.
[46] Hein, L., Bagstad, K. J., Obst, C., Edens, B., Schenau, S., Castillo, G., ... \& Caparrós, A. (2020). Progress in natural capital accounting for ecosystems. Science, 367(6477), 514515.

[47] Ali, B. J., \& Anwar, G. (2021). Academic Teaching Skills: Determining the Methods of Teaching to Undergraduate Students. Ali, BJ, \& Anwar, G.(2021). Academic Teaching Skills: Determining the methods of teaching to undergraduate students. International Journal of English Literature and Social Sciences, 6(3), 155-162.

[48] Cockcroft, S., \& Russell, M. (2018). Big data opportunities for accounting and finance practice and research. Australian Accounting Review, 28(3), 323-333.

[49] Syahputri, Y., Pribadi, T., \& Dalimunthe, H. (2020). The Implementation of Liability Accounting on Managerial Performance in PT. Telkom Tbk, Medan Branch. Budapest International Research and Critics Institute (BIRCIJournal): Humanities and Social Sciences, 3(3), 2395-2402.

[50] Ali, BJ, \& Anwar, G.(2021). Employee Turnover Intention and Job Satisfaction. International Journal of Advanced Engineering, Management and Science, 7(6), 22-30.

[51] Andiola, L. M., Masters, E., \& Norman, C. (2020). Integrating technology and data analytic skills into the accounting curriculum: Accounting department leaders' experiences and insights. Journal of Accounting Education, 50, 100655.

[52] Ali, B. J., Anwer, R. N. A. D., \& Anwar, G. (2021). Private Hospitals' Service Quality Dimensions: The impact of Service Quality Dimensions on patients' satisfaction. Int. J. Med. Phar. Drug Re, 7.

[53] Hörisch, J., Schaltegger, S., \& Freeman, R. E. (2020). Integrating stakeholder theory and sustainability accounting: A conceptual synthesis. Journal of Cleaner Production, 275, 124097.

[54] Ali, B. J., \& Anwar, G. (2021). Stock Exchange Investment: A Study of Factors That Influence Stock Exchange Investment. Ali, BJ, \& Anwar, G.(2021). Stock Exchange Investment: A Study of Factors That Influence Stock Exchange Investment. International Journal of Engineering, Business and Management, 5(3), 39-46.

[55] Kaya, C. T., Türkyılmaz, M., \& Birol, B. (2019). Impact of RPA technologies on accounting systems. Muhasebe ve Finansman Dergisi, (82).

[56] Ali, B. J., \& Anwar, G. (2021). Work Engagement: How Does Employee Work Engagement influence Employee Satisfaction?. Ali, BJ, \& Anwar, G.(2021). Work Engagement: How Does Employee Work Engagement influence Employee Satisfaction, 10-21.

[57] He, P., Niu, H., Sun, Z., \& Li, T. (2020). Accounting index of COVID-19 impact on Chinese industries: A case study using big data portrait analysis. Emerging Markets Finance and Trade, 56(10), 2332-2349.

[58] Hamad, K. Q., Qader, K. S., \& Sharif, R. J. M. (2021). Effectiveness And Adequacy Of Disclosure Provisions In Tehran Stock Exchange. PalArch's Journal of Archaeology of Egypt/Egyptology, 18(08), 2379-2388. 
[59] Ali, B. J., \& Anwar, G. (2021). Vocabulary Learning Strategies and Foreign Language Acquisition at Private Schools.

[60] Ali, BJ, \& Anwar, G.(2021). Vocabulary Learning Strategies and Foreign Language Acquisition at Private Schools. International Journal of English Literature and Social Sciences, 6(3), 163-173.

[61] Garbowski, M., Drobyazko, S., Matveeva, V., Kyiashko, O., \& Dmytrovska, V. (2019). Financial accounting of Ebusiness enterprises. Academy of Accounting and Financial Studies Journal, 23, 1-5.

[62] Ismeal, B. A., Aziz, H. M., Sorguli, S., Qader, K. S., Sabir, B. Y., Hamza, P. A., ... \& Anwar, G. (2021). The Role of External Auditing in Reducing Creative Accounting Practices.

[63] Ali, B. J., \& Anwar, G. (2021). Project Management and Dynamic Work Environments: The relationship between Leadership in Dynamic Work Environments in Kurdistan.

[64] Ali, BJ, \& Anwar, G.(2021). Project Management and Dynamic Work Environments: The relationship between Leadership in Dynamic Work Environments in Kurdistan. International Journal of Civil, Mechanical and Energy Science, 7(3), 10-18.

[65] Hamza, P. A., Sabir, B. Y., Qader, K. S., Aziz, H. M., Ismeal, B. A., Sorguli, S., ... \& Anwar, G. (2021). Global financial markets: Factors influencing the global financial markets.

[66] Ali, B. J., \& Anwar, G. (2021). Implementation of ELearning System Readiness: The Effect of the Cost Readiness on Implementing E-Learning.

[67] Ali, BJ, \& Anwar, G.(2021). Implementation of e-learning system readiness: The effect of the cost readiness on implementing e-learning. International Journal of Electrical, Electronics and Computers, 6(3), 27-37.

[68] Ali, B. J., \& Anwar, G. (2021). Anxiety and Foreign Language Learning: Analysis of Students' Anxiety Towards Foreign Language Learning.

[69] Ali, BJ, \& Anwar, G.(2021). Anxiety and Foreign Language Learning: Analysis of students' anxiety towards Foreign language learning. International Journal of English Literature and Social Sciences, 6(3), 234-244.

[70] Sorguli, S., Hamza, P. A., Ismeal, B. A., Sabir, B. Y., Aziz, H. M., Qader, K. S., ... \& Gardi, B. (2021). Adaption of EFilling of Income Tax Returns in Kurdistan.

[71] Ali, B. J., \& Anwar, G. (2021). Real Estates Strategies: Analysis of Strategic Management Practices in Real Estate Companies.

[72] Sabir, B. Y., Qader, K. S., Hamza, P. A., Ali, B., Ismeal, S. S., Aziz, H. M., ... \& Anwar, G. (2021). Analysis of Accounting-Based Measures of Expected Returns: A Study of Private SME In Kurdistan.

[73] Ali, BJ, \& Anwar, G.(2021). Real Estates Strategies: Analysis of Strategic Management Practices in Real Estate Companies. International Journal of Rural Development, Environment and Health Research, 5(3), 35-48.

[74] Qader, K. S., Ismeal, B. A., Aziz, H. M., Hamza, P. A., Sorguli, S., Sabir, B. Y., ... \& Gardi, B. (2021). The Effect of Human Resources Management Skills on Accounting Information Quality in Kurdistan Public Sector. Journal of
Humanities and Education Development (JHED), 3(3), 131143.

[75] Ali, B. J., \& Anwar, G. (2021). Administrative Crisis: The Role of Effective Leadership Styles in Crisis Management. Ali, BJ, \& Anwar, G.(2021). Administrative Crisis: The Role of Effective Leadership Styles in Crisis Management. International Journal of Advanced Engineering, Management and Science, 7(6), 31-41.

[76] Aziz, H. M., Sorguli, S., Hamza, P. A., Sabir, B. Y., Qader, K. S., Ismeal, B. A., ... \& Gardi, B. (2021). Factors affecting International Finance Corporation. Journal of Humanities and Education Development (JHED), 3(3), 148-157.

[77] Ali, B. J., \& Anwar, G. (2021). Corporate Social Responsibility: The Influence of Employee Engagement on Corporate Social Responsibility. Journal of Humanities and Education Development (JHED), 3(3), 77-83.

[78] Ali, BJ, Gardi, B., Othman, BJ, Sabir, BY, Sorguli, S., Ismael, NB, Hamza, PA, Aziz, HM, Ahmed, AA, Anwar, G.(2021). The Role of Shopping Malls on Kurdistan Regional Government's Economy. Journal of Humanities and Education Development, 3(3), 39-53.

[79] Ali, B. J., \& Anwar, G. (2021). Porter's Generic Competitive Strategies and its influence on the Competitive Advantage. Ali, BJ, \& Anwar, G.(2021). Porter's Generic Competitive Strategies and its influence on the Competitive Advantage. International Journal of Advanced Engineering, Management and Science, 7(6), 42-51.

[80] Anwar, G., \& Abdullah, N. N. (2021). A Project Management Improvement Program: Enhancing Production With Implementing the Knowledge Management Principles. Advanced Engineering Science, 46(1).

[81] Aziz, H. M., Sorguli, S., Hamza, P. A., Sabir, B. Y., Qader, K. S., Ismeal, B. A., ... \& Gardi, B. (2021). Factors affecting International Finance Corporation. Journal of Humanities and Education Development (JHED), 3(3), 148-157.

[82] Anwar, K. (2017). Analyzing The Conceptual Model Of Service Quality And Its Relationship With Guests'satisfaction: A Study Of Hotels In Erbil. The International Journal of Accounting and Business Society, 25(2), 1-16.

[83] Ali, BJ, Gardi, B., Othman, BJ, Ismael, NB, Sorguli, S., Sabir, BY, Ahmed, SA, Hamza, PA, Aziz, HM, Anwar, G.(2021). Educational system: The policy of Educational system in Kurdistan Region in public Kindergarten. International Journal of English Literature and Social Sciences.

[84] Anwar, K. (2017). The Role of Effective Leadership in Crisis Management: Study of Private Companies in Kurdistan. Qalaai Zanist Scientific Journal, 2(4), 326-338.

[85] Anwar, K., \& Louis, R. (2017). Factors Affecting Students' Anxiety in Language Learning: A Study of Private Universities in Erbil, Kurdistan. International Journal of Social Sciences \& Educational Studies, 4(3), 160.

[86] Anwar, G. (2015, April). Vocabulary Learning Strategies Of English Language Learners In Northern Cyprus. In BOOK of PROCEEDINGS (p. 226). 
[87] Gardi, B. (2021). The effects of computerized accounting system on auditing process: a case study from northern Iraq. Available at SSRN 3838327.

[88] Anwar, G., \& Shukur, I. (2015). Students' Attitudes towards Learning English Language in Erbil. International Journal of Social Sciences \& Educational Studies, 1(4), 17.

[89] Hameed, A. A., \& Anwar, K. (2018). Analyzing the Relationship between Intellectual Capital and Organizational Performance: A Study of Selected Private Banks in Kurdistan. International Journal of Social Sciences \& Educational Studies, 4(4), 39.

[90] Abdullah, M. S., Toycan, M., \& Anwar, K. (2017). The cost readiness of implementing e-learning. Custos E Agronegocio On Line, 13(2), 156-175.

[91] Ismael, N. B., Sorguli, S., Aziz, H. M., Sabir, B. Y., Hamza, P. A., Gardi, B., \& Al-Kake, F. R. A. (2021). The Impact of COVID-19 on Small and Medium-Sized Enterprises in Iraq. Annals of the Romanian Society for Cell Biology, 2496-2505.

[92] Anwar, K., \& Balcioglu, H. (2016). The relationship between transformational leadership characteristics and effectiveness: A case study of construction companies in Erbil. International Journal of Science Technology and Management, 5(2), 250-256.

[93] Anwar, K. (2016). Comparison between cost leadership and differentiation strategy in agricultural businesses. Custos E Agronegocio on Line, 12(2), 212-231.

[94] Gardi, B. (2021). Investigating the effects of Financial Accounting Reports on Managerial Decision Making in Small and Medium-sized Enterprises. Available at SSRN 3838226.

[95] Ali, BJ, Gardi, B., Othman, BJ, Ahmed, SA, Ismael, NB, Hamza, PA, Aziz, HM, Sabir, BY, Anwar, G.(2021). Hotel Service Quality: The Impact of Service Quality on Customer Satisfaction in Hospitality. International Journal of Engineering, Business and Management, 5(3), 14-28.

[96] Anwar, K. (2017). Leading Construction Project Teams: The Effectiveness of Transformational Leadership in Dynamic Work Environments in Kurdistan. International Journal of Advanced Engineering, Management and Science, 3(10), 239925.

[97] Ismael, NB, Othman, BJ, Gardi, B., Hamza, PA, Sorguli, S., Aziz, HM, Ahmed, SA, Sabir, BY, Ali, BJ, Anwar, G.(2021). The Role of Training and Development on Organizational effectiveness. International Journal of Engineering, Business and Management, 5(3), 15-24.

[98] Anwar, K., \& Ghafoor, C. (2017). Knowledge management and organizational performance: A study of private universities in Kurdistan. International Journal of Social Sciences \& Educational Studies, 4(2), 53.

[99] Anwar, K., \& Qadir, G. H. (2017). A Study of the Relationship between Work Engagement and Job Satisfaction in Private Companies in Kurdistan. International Journal of Advanced Engineering, Management and Science, 3(12), 239944.

[100] Anwar, K. (2017). Factors affecting stock exchange investment in kurdistan. The International Journal of Accounting and Business Society, 25(1), 32-37.
[101] Ahmed, SA, Othman, BJ, Gardi, B., Sabir, BY, Ismael, NB, Hamza, PA, Sorguli, S., Aziz, HM, Ali, BJ, Anwar, G.(2021). Students' Attitudes towards Learning English in the Kurdistan region of Iraq. International Journal of English Literature and Social Sciences, 6(3), 072-087.

[102] Anwar, K., \& Climis, R. (2017). Analyzing the relationship between types of advertisement and customer choice: a study of retailer stores in erbil. The International Journal of Accounting and Business Society, 25(2), 43-52.

[103] Sorguli, S., B. Gardi, B. J. Othman, H. M. Aziz, S. A. Ahmed, B. Y. Sabir, N. B. Ismael, P. A. Hamza, B. J. Ali, and G. Anwar.(2021). "Innovation: Knowledge Management in the Innovating Industries, 6 (3), 10-23."

[104] Anwar, K., \& Louis, R. (2017). Factors Affecting Students' Anxiety in Language Learning: A Study of Private Universities in Erbil, Kurdistan. International Journal of Social Sciences \& Educational Studies, 4(3), 160.

[105] Ali, B. J., \& Anwar, G. (2021). The mediation role of change management in employee development. Ali, BJ, \& Anwar, G.(2021). The Mediation Role of Change Management in Employee Development. International Journal of English Literature and Social Sciences, 6(2), 361-374.

[106] Aziz, HM, Othman, BJ, Gardi, B., Ahmed, SA, Sabir, BY, Ismael, NB, Hamza, PA, Sorguli, S., Ali, BJ, Anwar, G.(2021). Employee Commitment: The Relationship between Employee Commitment And Job Satisfaction. Journal of Humanities and Education Development, 3(3), 54-66.

[107] Ali, B. J., \& Anwar, G. (2021). Measuring competitive intelligence Network and its role on Business Performance. International Journal of English Literature and Social Sciences, 6(2).

[108] Sabir, B. Y., Jabbar Othman, B., Gardi, B., Burhan Ismael, N., Abdalla Hamza, P., Sorguli, S., ... \& Anwar, G. (2021). Administrative Decentralization: The Transfer of Competency from The Ministry of Education to General Directorates. International Journal of Rural Development, Environment and Health Research (IJREH), 5.

[109] Ali, BJ, Anwar, G., Gardi, B., Othman, BJ, Aziz, HM, Ahmed, SA, Hamza, PA, Ismael, NB, Sorguli, S., Sabir, BY (2021). Business Communication Strategies: Analysis of Internal Communication Processes. Journal of Humanities and Education Development, 3(3), 16-38.

[110] Anwar, G. (2015, April). Vocabulary Learning Strategies Of English Language Learners In Northern Cyprus. In $B O O K$ of PROCEEDINGS (p. 226).

[111] Hamza, P. A., Othman, B. J., Gardi, B., Sorguli, S., Aziz, H. M., Ahmed, S. A., ... \& Anwar, G. (2021). Recruitment and Selection: The Relationship between Recruitment and Selection with Organizational Performance. International Journal of Engineering, Business and Management, 5(3), 113.

[112] Anwar, G., \& Shukur, I. (2015). Students' Attitudes towards Learning English Language in Erbil. International Journal of Social Sciences \& Educational Studies, 1(4), 17. 